Rath, J., 'Research on immigrant ethnic minorities in the Netherlands', pp. 137-159 in P. Ratcliffe (ed.), The Politics of Social Science Research. 'Race', Ethnicity and Social Change. Houndmills, Basingstoke, Hampshire: Palgrave, 2001.

\title{
Research on immigrant ethnic minorities in the Netherlands'
}

Jan Rath

\section{Introduction}

No country in the world has such a high concentration of social scientists as the Netherlands, and this is particularly evident in those social areas which are publicly recognized as problem areas. Research into post-migratory processes is an example. Up to and throughout the 1970s only sporadic research was done, but this picture changed spectacularly after 1980. In that year the state accepted officially that 'guest workers' from Mediterranean countries and 'fellow citizens' (rijksgenoten) from former colonial territories were in fact immigrants and not temporary visitors. At the same time the state judged it necessary to develop a coherent minorities policy in which the political goal of the integration of 'ethnic minorities' - as the people involved came to be calledshould be achieved. One thing and another led to an explosive growth in what was called 'minorities research'. Many thousands of projects were started, and so far approximately 6,0007,000 academic articles achieved publication, an average for the past two decades of almost one a day. ${ }^{1}$ Truly a bounteous harvest. The score is particularly high in the sectors comprising education, health, housing and employment.

The scale is not the only surprising thing about minorities research; the speed with which it was institutionalized is also striking. For example, in 1978 the Minister of Culture, Recreation and Social Work set up the Advisory Commission for Research into Cultural Minorities (ACOM) which gave a powerful spur to the industry. In 1983 the Minister of Education and Science established two new chairs for the study of multi-ethnic societies, one in Amsterdam and one in Utrecht, soon to be followed by a series of other chairs for inter-cultural communication, bilingualism and the like. The Netherlands Organization for Scientific Research (NWO) in 1988 gave official recognition to the study group for the Social and Cultural Studies of Ethnic Minorities, which at the time had more than a hundred members, while the Netherlands Foundation for Legal Academic Research (NESRO) and the Foundation for Research in Theology 
and Religious Studies in the Netherlands (STEGON) also established specialized working parties and funding programmes. In addition there are at present a variety of academic institutes specializing in whole or in part in research into minorities, and since 1985 there has even been a specialist journal Migrantenstudies. Anyone aware of the speed with which this growth has occurred, must be impressed. There is no question that we are faced with an exceptionally active sector of the social science industry.

Paradoxically, the more reflective publications about minorities research have a predominantly doubtful and pessimistic tone. Minorities researchers from the very beginning — such as Van Amersfoort (1982a, 1983 and 1991), Bovenkerk (1984; see also Bovenkerk, Miles and Verbunt (1991), Ellemers and Borghuis (1988), Köbben (1980), Penninx (1988b), Van Praag (1987) and Shadid and Van Koningsveld (1986), but also Van Doorn (1985), Gelling, De Jong and Schoemaker (1990), Jongkind (1992), Monsma (1987), Tinnemans (1991), Waardenburg (1986) and several others-complain particularly about the sparseness of theoretical results. In their judgement the academic output has been mainly descriptive, not particularly high in quality, and has led to hardly any accumulation of knowledge. There is little connection with theoretical writings in other countries, and in so far as researchers have dared to enter the territory of international comparative studies they have made no real contributions to the advancement of theory. Van Doorn (1985: 75) described this condition as 'academic provincialism'.

In its generality this diagnosis of minorities research is a fair one. There are certainly researchers who are interested in theoretical issues, but when it comes down to it, their analyses and observations have often become bogged down at a low level of abstract thought, and have limited significance. Yet the diagnosis is not a complete one. There is yet another serious shortcoming, and this is that minorities researchers often start from the same theoretical premises, so that their research is into more or less the same aspects and processes, and systematically fails to take others into consideration. This means that minorities research not only suffers from being superficial in theory, but also from a one-sidedness in its conceptual framework. In this context the fact that this weakness is ignored in almost all meta-analyses—except that of Bovenkerk (1984)—is a telling example. There may indeed be a general consensus about the epistemological foundations of the research, but as yet there has been little room for debate.

As I have demonstrated in detail elsewhere (Rath 1991: 30-58; see also Rath 1993, and 1997), most minorities research falls within the 'ethnicity paradigm', as described by, among others, Omi and Winant (1986). This paradigm starts from the assumption that ethno-cultural distinctions are 
the most important social distinctions. Ethno-cultural differences are accepted as being differences of an essential nature, caused in this context by the arrival of people from foreign parts of the world. The maintenance of ethno-cultural characteristics is not without its obligations. After all, the newcomers are living within the unitary Dutch culture of the majority; by not adjusting to the pattern of the society surrounding them they are putting their social position at risk—so goes the argument. Their adaptation to this society is to be desired and in fact can hardly be avoided. Those categories who none the less fail to adapt adequately, and in addition have to contend with social disadvantages over a long period, are labelled as 'ethnic minorities'. These minorities can only make up for their disadvantages in one way; by a process of integration controlled by the 'majority'. Van Amersfoort's book Immigration and the Formation of Minority Groups (1982) can in a sense be regarded as the theoretical sublimation of Dutch minorities research. ${ }^{2}$

Let me illustrate this with an example. Take research on immigrant entrepreneurship. Most researchers show a great deal of interest in ethno-cultural characteristics and processes of ethno-cultural incorporation (Rath \& Kloosterman 1999). Completely in line with Dutch ethnic minorities research, they regard entrepreneurship in ethnic terms, something which is illustrated by the indiscriminate and unthinking use of the term 'ethnic entrepreneurship'. Exactly what distinguishes ethnic entrepreneurship from entrepreneurship in general-the origins of the entrepreneur, management strategies, personnel, the clientele, the products, or a combination of these?-is seldom or never (theoretically) made explicit. Most researchers just assume that there are real differences, just because they are dealing with immigrants. They subsequently search for ethno-cultural traditions, ethnic moral frameworks, ethnic loyalties, ethnic behaviour patterns, and ethnic markets and compare the entrepreneurship of different ethnic groups. In so doing, they reduce immigrant entrepreneurship to an ethno-cultural phenomenon existing within an economic and institutional vacuum. Little systematic attention is paid to the structural changes through which the economy as a whole is going or which specific parts of the market are experiencing, or to the institutional framework of the welfare state within which entrepreneurs operate. ${ }^{3}$ They thus behave as if the market is of little importance, as if bakers, garages, ice-cream parlours, clothing manufacturers and marketing bureaux operate under more or less identical market conditions, fall under the same regulations and institutions, demand similar entrepreneurial skills of the entrepreneurs, and produce similar trading results. Obviously, this is not the case. The strong rise of Turkish clothing contracting firms in Amsterdam during the 1980s and the beginning of the 1990s, for instance, was very much linked to the changing consumption patterns and purchasing strategies of wholesalers and chain stores, as well as the fairly tolerant attitude of the relevant authorities towards informal 
practices. The collapse of this industry halfway through the 1990s was linked to the opening of new markets in East Europe and with the more rigorous control on illegal work and tax evasion. This example shows the extent to which processes external to the entrepreneurs and their businesses, can boost and thwart entrepreneurship. The minorities paradigm, however, fails to adequately appreciate these processes.

The hegemony of the ethnicity paradigm is overwhelming. The two other paradigms distinguished by Omi and Winant are rarely encountered in the Netherlands. Only a handful of researchers take account of the 'nation paradigm' or the Marxist variants of the 'class paradigm'. It is this last which I would like to discuss here.

Out of a comprehensive summary of what has been published, comprising many thousands of books and articles about ethnic minorities in the Netherlands, some two dozen can be identified of which the inspiration is based on some version of Marxist theory. ${ }^{4}$ This inspiration is not always expressed in as many words - sometimes it is a question of eclecticism - while in many cases the theory is limited to the superficial. A salient feature is that most of these publications date from the 1970s when the phenomenon of guest workers was still relevant. They emphasized the asymmetrical development of international economies as a cause of guest work and referred to the role of state as the bourgeoisie's keeper: the industry was only interested in the economic advantages of foreign labour, while the state stood by to provide solutions to the contradictions to which it gives rise. In this perspective guest workers were part and parcel of the working class, or of a kind of new class under it. Most of the writers argued that the classic workers organizations, such as the trades unions and socialist parties took too little account of the interests of immigrant workers, or even deliberately allowed the interests of the native-born section of the working class to take precedence. In practice the much-praised ideology of international solidarity came to nothing. Only a few writers took a more finely-tuned theoretical position.

In the context of the international academic debate on the subject, especially in the 1970s and 1980s, the unpopularity of the class paradigm in the Netherlands is rather odd. In this period, various other West-European countries, such as Great Britain, Germany and France, plenty of researchers found their inspiration in Marxism (for overviews see among others Solomos 1986; Kalpaka \& Räthzel 1992). In their own countries, and also outside it, they carried on lively debates about the role of the state, about racism or about the interrelationships between race, ethnicity, gender, class and state. Oddly enough most Dutch social scientists avoided this debate. Although in the early 1970s some researchers showed interest, later on most of them almost 
completely turned away from this tendency. De Jong's study of 1986 illustrates this excellently: in his fairly complete review of theories about inter-ethnic relationships, Marxist theories were completely lacking.

Various other researchers went even further: they explicitly and categorically rejected any arguments that tended towards Marxism. Interestingly, the most pronounced criticisms were advanced by academics who already for many years assumed positions of authority in minorities research. The critics were influential researchers who had to an important extent determined the shape of Dutch minorities research, and are still doing so. This fact gives their categorical rejection of Marxist theory extra significance.

For example, van Amersfoort (1982b: 63-66) stated that 'the concept of class is, in general, difficult to use in the analysis of minority situations'. In his inaugural lecture (1987: 20) he was if possible even more firm: '[...] a Marxist class model [can] not be applied to the situation of immigrants in Western Europe, not even if one is prepared to modify the model drastically.' Van Doorn (1985: 80) was scornful about the stratificational and historically materialist reductionism of some theoretical tendencies which did not recognize ethnicity and ethnic groups as autonomous phenomena. Entzinger in his inaugural lecture (1987a: 9) stated that the adherents of what he called 'the antiracism model' wrongly tended to regard 'class and race differences' as 'of the same order' and as 'the result of [...] exploitation', and engaged in 'moralizing'. Hoppe (1987: 11) accused Dutch political science of grossly disregarding the subject of the politicizing of ethnicity by, among other things, "explaining away ethnicity through subsuming it among "more general" social inequalities such as class or socio-economic status'. Penninx (1988a: 40-41) in the 1980s had - contrary to his attitude in the 1970s-little time for 'the Marxist approach' because 'in welfare states such as the Netherlands' 'its core concepts are not (or cannot) be accurately defined'. Finally, van Praag (1987: 170), referring to Marxist writers, sniffed at the 'tendencies in the British "sociology of race relations" in which people hardly did more than embodying the requirements of the capitalist system'. ${ }^{5}$

The question arises whether these social scientists were not once again displaying a sample of their academic provincialism? Or did they really have good academic grounds for consigning all Marxist theory to the dustbin?

This is the subject to be discussed here. This article first highlights the ways in which prominent Dutch minorities researchers dismissed Marxist theory. After that comes a discussion on the 
reasons for this negative attitude, and on how far the stated objections are tenable. Finally an attempt is made to find an explanation for the absence of Marxist theory in minorities research.

\section{Categorical Rejection of Marxism: The Arguments}

Let us see what arguments were used by academic researchers to support their challenge to Marxism. What did their destructive criticism amount to?

Van Amersfoort (1987: 19-20) in his inaugural lecture examined the settlement pattern of migrants in Amsterdam and for this purpose checked the practicability of several 'conceptual frames'. One of them was the concept of 'the city as a mirror of fundamental differences'. Pahl (1970), the social geographer, was an exponent of this idea, and pled for an analysis of the basic conflicts between the haves and the have-nots. Van Amersfoort condemned Pahl on the grounds that he did not explain precisely how these classes had to be operationalized. Perhaps van Amersfoort might have ventured an attempt at this himself, but he chose to repeat his opinion that a 'Marxist class model' was not relevant to the situation in Europe. In a note he referred the reader to the English edition of his dissertation (1982b: 63-66; see also 1974: 70-72). This contains his criticism of the unidimensionality of the Marxist tradition. In his view the adherents of this tradition only recognized 'one valid form of social inequality that divides all people [...] in two categories which assume contradicting positions'. The fundamental criterion in this for an industrial society is the labour market and in particular the ownership of the means of production; all other forms of inequality derive from this. The attempt by Dahrendorf-whom he curiously considered as representative of Marxism — to modify the theory, in part by suggesting that 'all bureaucratic personnel must be reckoned among the ruling class', was in Van Amersfoort's view no improvement. His main objection was that this sharp dichotomy did not do justice to the situation in which minorities find themselves, because on the basis not of one, but of a variety of criteria, they occupied a position in one or more continuous hierarchies. He next launched a broadside at the American Marxist writer O.C. Cox. In 1948 Cox resolved the relationship between whites and blacks in the southern United States completely to one of class struggle and characterized 'racial prejudices as a manoeuvre by the white elite to keep poor whites from becoming aware of their real class position'. Cox was convinced that 'the Negroes' class position is the same as that of a part of the whites'. Van Amersfoort thought it rather clumsy to regard the existence and the continuation of the differences within a single class as 'fake or unreal, or that 
they are a trick of the ruling clique'. He concluded: 'They apparently belong to the sort of contrasts that cannot be analysed with the class concept'.

Van Doorn (1985: 76-82) based his judgement on a reference to Marx himself, who, according to him, negatively evaluated the signification of nationality and ethnicity. Where a distinction arising from descent and local roots did occur, "they are "accidental" and are not part of the "real" problem: that of the class society'. Both were crystal clear from Marx's own interpretation of the Irish question. Van Doorn thought that Marx was convinced that the problems in Ireland were economic in nature, and he rejected this reductionism.

According to Entzinger (1984: 249; see also 1987b: 5-8), Marxists claimed that the entrepreneurial class took advantage of immigration to destroy the unity of the working class and thus their ability to oppose exploitation. The capitalists gambled on latent racism, and thus divided the immigrants as a sub-proletariat from the native-born proletariat. The interests of the capitalist production system were served by keeping the immigrants in a subordinate exploited position. In Entzinger's inaugural lecture (1987a: 9) this caricature turned up again in a paragraph where he described 'the antiracism model'. He claimed there that Marxists treated as one class and race differences, whereas they should in fact be distinguished from each other at an analytical level. He also poured scorn on the determinism in Marxism. 'Ethnic distinctions would be doomed to disappear $[\ldots]$ because these distinctions are overshadowed by class differences.'

Penninx's (1988a: 38-41) rejection of the Marxist approach came in a paragraph about the 'discriminatory point of view', which according to him is one of the seven from which minorities researchers work in the Netherlands. He argued that this point of view is relatively new both in the Netherlands and abroad, and had to an important degree developed in minority circles themselves. This observation did probably not refer to Marxism but only to the theoretical positions involving 'institutional racism' or 'white racism' which Penninx for convenience' sake treated under the same heading. They are, in fact, all concerned with power and the inequalities of power relationships between groups, he said briefly, and together they make the 'social and political position' of migrants more crucial than the 'ethno-cultural position'. The first comment is certainly true, but still not sufficient reason to consider these approaches as being of equal importance; it is a question of fundamentally different power relationships. And as for the second: Marxists paid particular attention to the dialectical relationships between both positions, and would never consider treating these positions as separate phenomena (cf. $\mathrm{Ng} 1989$ ). Penninx, however, said about the Marxist approach that "its adherents claim the "black problem" originates 
in developments in capitalism, and emphasize the special role of the state and of government as the implementer and protector of the interests of capital'. Like van Amersfoort, Penninx maintained that the operationalization of the core concepts of the Marxist approach, such as that of class, is problematic, particularly in the modern welfare state.

Finally, van Praag (1987: 168-173) slipped his criticism into a passage in which he commented on the demand for theory. He referred to Britain and suggested that minorities research there was still at the stage of 'rival theories of oppression, which appear to be linked to ideological positions' The basic pattern is a 'classical Marxist structural analysis', which, however, cannot account for all the facts. Which facts Van Praag did not say. Further on he contrasted the assimilation theory of the German sociologist Esser (1980) with the Marxist tendencies in what he called the 'British sociology of race relations'. He characterized both 'exploded attempts to form theories' as reductionist. Hence the Marxists would only regard people as pawns of capitalism.

\section{Comment}

Are these arguments, albeit sometimes perhaps too briefly summarized, valid and sound enough to support the rejection of the whole body of Marxist theory? First a small but still telling point. In his criticism of British Marxism, van Praag categorized the British sociologist Miles as an exponent of the 'sociology of race relations', and he referred to Miles' book Racism and Migrant Labour (1982). But if there is one writer who has repeatedly and bitterly inveighed against the sociology of race relations, and has consequently distanced himself from such a categorization, it is Miles. For instance, in the introduction to the book mentioned, Miles emphasized (Ibid:: 1-6; see also 1984 and 1989) with the greatest possible stress that ideas like 'race' and 'race relations' have no analytical value. ${ }^{6}$ The sociology of race relations is obsessed by 'race', and therefore systematically distorts our comprehension and analysis of the position of migrants, in Miles' view. Evidently van Praag had not read this passage properly, and this raises serious fears about his criticism of the rest of the book. There is small comfort. As shall appear, he is not the only one who had studied this frequently quoted book with too little care.

We will now unravel the inherent arguments against Marxism and examine them one by one on their merits. A regularly recurring argument was the unidimensionality of Marxists. They were accused of having a stereotyped vision of society and of reducing all social phenomena to the social classes or to their function in the economic processes. But is it in fact true that Marxists 
reduced ethnic or racial relationships to class relationships, or that they regarded racism as a functional element of the process of economic accumulation? Van Amersfoort referred to Cox as a representative example of this, and Entzinger and Van Praag referred to Castles and Kosack (1973) and to Miles. It is certainly the case that Cox, and Castles and Kosack, presented a somewhat reductionist and economic-determinist vision of reality. Cox's Caste, Class and Race (1948) is, however, more than fifty years old, and was already in the late 1970s no longer taken seriously in Marxist circles. On the contrary, the occasional references by writers to Cox's early and not so early works exposed the one-sidedness and inadequacy of this mechanistic view and rejected it as a product of their time (see for example Gabriel \& Ben-Tovim 1978: George 1984: 139-144; Miles 1980, and 1982: 81-87; Solomos 1986: 87-88). Thus Solomos stated that:

'the model of Marxism with which Cox was familiar was based on the conceptual baggage of "base" and "superstructure" and an instrumental view of the state as the agent of the capitalist class. [...] This adherence to such views runs counter to the main tendency of contemporary Marxist analysis, which in fact has evolved a number of competing schools of thought, and whose central concern is to question the tenability of the classical base-superstructure model as a conceptual framework.'

He then referred to Przeworski (1977; see also Wright 1980), who pointed out that 'the traditional separation between the economic definition of classes and the political and ideological determinants of class-formation is in fact quite misleading when it comes to the concrete analysis of the contradiction that arises either within or between social classes. Przeworski argued, and here he expressed a view shared by most Marxist writers in the 1980s, that it is not possible 'to separate the "objective" analysis of class from the totality of economic, ideological and political relations which organise, disorganise and reorganise social classes as a result of class struggles and historical transformations.' Solomos concluded that it would be 'quite mistaken' to suppose that modern Marxist writings about races and classes was derived from Cox.

Miles_-who, as has already been said, was accused by some Dutch authors of economic determinism—-had many times been sharply critical of Cox for his... economic determinism. He demonstrated that Cox was misinformed and logically inconsistent, and had got it all wrong when he considered class and race as two specific types of the same phenomenon. Miles (1980: 186) said about Cox:

'If that formulation is to be regarded as a work of Marxist scholarship (I tend to the view that it should not), then it is most certainly inadequate but [...] the fault lies not in some inherent aspect of Marxism but in Cox's formulation of the concepts of political class and ethnic system. Herein lies a double challenge to those who believe that, in demolishing Cox's 
analyses, they have proven that Marxist theory cannot "cope" with race relations and to those Marxists who believe that Cox's analyses constitutes the Marxist analysis of an empirical epiphenomenon of the class struggle.'

Here Miles targeted Castles and Kosack who (in 1972) heartily endorsed Cox's 'superb work of Marxist scholarship' (Castles \& Kosack 1972: 16n).

The most quoted publication by Castles and Kosack, Immigrant Workers and Class Structure in Western Europe, dated from 1973 and was about the effects of migrant labour and the position of the migrant workers themselves. It is a classic book which for that matter collected praise in (neo)Marxist circles, at least in so far as the writers-unlike more conventional writers-drew connections between the political, social and ideological demands of capitalism and migrant labour (Cohen 1987: 138) and in so far as they criticized those studies which dealt only with the problems of assimilation of individual migrants (Miles \& Satzewich 1990: 336). However, this left the most severe criticism untouched. Eleven years after this publication Castles (with Booth and Wallace 1984) came out with a more balanced view, from which it seemed that he had taken account of some of the criticisms of his standard work written with Kosack. This shift had evidently escaped Entzinger (1987a), who as a matter of fact was the only one to mention this more recent book. Like van Praag (1987), he mentioned Castles and Kosack in the same breath with Miles, and claimed that they all embrace the discredited and stereotyped Marxist opinions to the same degree.

The failure to differentiate between these writers is remarkable because Miles was in fact one of those who vented fairly severe criticism of the views put forward by authors like Castles and Kosack. Even more, this criticism started the development of a whole new point of view. In Racism and Migrant Labour (1982; see also Miles \& Satzewich 1990) Miles gave Castles and Kosack a piece of his mind. Like Cox and writers such as Nikolinakos and Sivanandan, Castles and Kosack claim that migrant work fulfilled an economic and socio-political function for capitalism, as a fresh reservoir of labour and as a means of dividing the working class. They further located the origin of racism in capitalist expansion only. Miles (Ibid.: 81-87; 152-153; 165166; see also 1989), however, rejected the functionalist nature of this explanation of the origin of racism. In his view racism did not originate in a conspiracy by capitalists any more than racism was the privilege of the ruling class, or limited to the idea of whites over blacks. In Castle and Kosack's view, working class racism was not an independent phenomenon but only the product of the divide-and-rule policy of the bourgeoisie and its agent, the state. But Miles suggested, on the other hand, that the ruling class gained no benefit from conflicts within the working class and that 
neither the capitalists nor the state had an interest in stirring up racism. In his view it was a mistake to look for the origins of racism in the simultaneous growth of capitalism and colonialism. Miles also opposed the assumption that the development of racism had been linear. Racism is a far from homogeneous phenomenon, and anyone who, like Castles and Kosack, maintained that this is the case, ignored the specific character that racism assumes in different situations. This occurred, Miles continued, because Castles and Kosack applied an economistic definition of class, and take too little account of the influence of current political and ideological relationships on the process of class formation, including the more autonomous role of the state. The result is a rather linear concept of class relationships. Castles and Kosack made it seem as if the working class once formed a homogeneous bloc against the bourgeoisie, but that after the immigration of migrant workers it was split in two purely and simply because the natives and the immigrants occupied different economic positions. Miles rejected this view and maintained that the working class was fragmented long before there was any immigration. With this Miles rounded off his catalogue of the main theoretical arguments against Castles and Kosack's work. It should be noted that Miles, the neo-Marxist, was here putting forward precisely the same arguments, plus a few additional ones, with which Entzinger and van Praag used to fulminate against 'Marxism'. How they had managed to achieve such a negative judgement about the whole of Marxist theory, and particularly about Miles, is unclear. They still actually acknowledged Miles (1982) as their source.

Another argument against Marxism was the operationalization of the concept of class (van Amersfoort 1987; Penninx 1988a). Definition of classes by objective criteria is always a problem, said Penninx, but on the grounds of subjective ones (class consciousness), it is hardly possible to do so meaningfully, particularly so in modern welfare states. Penninx offered no proof for this statement, or even the beginning of a clarification, but it is possible to suspect where the shoe pinches. Before the coming of the welfare state things were quite simple. In the nineteenth century - say in the time of Marx and Engels - it was easy to describe relationships of production. Those who owned the means of production belonged to the entrepreneurial class, and everyone else to the working class. Workers could only generate income in one way, and that was by selling their labour to the entrepreneurs. They in their turn could generate capital by creaming off the surplus value of the work. The state played no significant role in this process; the little that they did do was to protect the interests of capital. With the rise of the social or Christian democratic welfare state in the course of the twentieth century, this picture changed dramatically. The state began to intervene in the economic, social and political life of its citizens, and in an unprecedented way. It invested on a large scale, redistributed financial resources and provided an income for a substantial part of the population, either by taking them into their service as a labour force (the 
state became in fact the largest employer), or by subsidizing institutions in whole or in part, or by giving them a straightforward remittance. Besides it had carried out numerous measures which influenced not only the process of economic accumulation, but also social and political relationships and the prevailing ideology. Also, or perhaps rather because the state imposed such a powerful stamp on society, and no longer acted just as the agent of capital, the simple nineteenth century concepts of working class and bourgeoisie were no longer adequate descriptions of present-day reality. Well. if these were the objections to applying Marxism to the minorities issue, they were not in the least convincing, because these were exactly the things that were occupying the attention of many Marxists in the 1980s: what is the post-industrial mode of production, how does the process of class formation develop, and what is the role of the state in this? Van Amersfoort (1982b) paraphrased Dahrendorf who maintained that the state bureaucracy is de facto part of the ruling class, or in any case acts as the accomplice of capital. His attempt to remove in this way the concept of class, among other things, from its historical context, was considered unsatisfactory in van Amersfoort's eyes. But was Dahrendorf's theory really a good model for modern Marxism? Far from it. This is not to claim that operationalizing presents no problems. ${ }^{7}$ But the point here is that Van Amersfoort and Penninx pushed the problem of operationalization to the front, without seriously considering what Marxists had to contribute on the subject. Their criticism rested on a fortuitous knowledge of a few old-fashioned sources, and certainly not on any review of modern Marxist theory.

In conclusion we can say that the categorical rejection of Marxist theory by Dutch minorities researchers was not based on tenable arguments. The critics based their rejection mainly on a few (hopelessly) outdated studies which they wrongly believed were representative of 'the Marxist approach'. Although their criticisms of these old studies were justifiable in places, they had little relevance to the overall tendency and even less to neo-Marxist schools of thought. These critics had tragically enough completely overlooked the fact that these Marxists had uttered more or less the same criticisms; and had overlooked it in some cases after claiming to have studied the literature involved. The obviousness with which Marxist theory was habitually denounced was evidently so great that they refrained a priori from acquainting themselves sufficiently with the latest theoretical developments. Their judgement therefore said more about their failure to understand the modern literature than about Marxist theory itself.

\section{The Political Nexus}


Why was it that minorities researchers in the Netherlands had been so little inspired by theory, and above all wanted to have so little to do with Marxist theory? The answer to this question lies in the tradition of Dutch social science research which is embedded in the typical way in which the nation-state has developed. During an earlier historic period, the Netherlands had become a society in which religion and philosophies of life were the most important social determinants and in which the struggle for resources took the shape of a struggle between social groupings which were formed on the basis of religion or philosophy of life. These social groupings constituted so-called 'pillars': these were more or less closed communities within which all social life-from the cradle to the grave—took place (Lijphart 1975; van Schendelen 1984). Each group had its own institutions, varying from hospitals, daily and weekly newspapers, broadcasting systems, schools, universities, sporting clubs, (trade)unions and political parties. There was very little social interaction between them, with the exception of those at the top who took responsibility for the accommodation between pillars. Political leaders consulted and debated amongst themselves, settled possible conflicts and looked after the interests of their pillar well, thereby taking account of the feelings of other pillars and ensuring that each pillar would get an equal piece of the pie. In the developing welfare-state the 'pillarized' organizations were closely involved with the formation and implementation of government policy and, not in the least, with the distribution of social goods and services to citizens-an activity which sanctioned their raison d'etre. These activities were not only firmly anchored in social and political practice, but also in rules and regulations. This system contributed to social stability in a society that was otherwise marked by sharp cleavages between the various religions and philosophies of life.

Within this system, it was common practice not to make a hot issue of something; sensitive subjects were usually resolved by a technocratic compromise. In that process experts had acquired a predominant, if instrumental role. Hence a type of social science research had arisen with strong politically directed traits, and a type of researcher who saw his or her task primarily as one of service to the community, and who adjusted his academic work to the political theory which is agreeable to the state and to the political parties (Gastelaars 1985). To paraphrase the criminologist Fijnaut (1990: 269), researchers allowed themselves to be 'intellectually domesticated'. These circumstances, occurring in a society in which religious and philosophical divisions have blurred class divisions, seemed not to offer a favourable culture for the sustained development of an academic tendency based on Marxism. ${ }^{8}$ 
This is precisely what had happened in minorities research. As has already been mentioned, minorities research only really took off after the state had developed their own minorities policy. In the mid-1970s, this Minister of Culture, Recreation and Social Work (CRM)—the main promoter of the minorities policy - came to the conclusion that providing welfare to guestworkers and fellow citizens from former colonial territories would not really alleviate their problems with regard to labour, housing, education or legal security. Other ministries had to assume their responsibility and address the issue as well. However, the others were not straight away convinced that this was really necessary for people who-in their view-would anyway return to their homelands. The Ministry of CRM then embarked on a kind of missionary project in order to persuade the other ministries to take on board the new paradigm that guestworkers and fellow citizens actually constituted ethnic minorities on whose behalf a coherent ethnic minorities policy should be developed. At the time, van Amersfoort's dissertation $(1974,1982)$ was circulated on a wide scale at the ministry, and one of its public officials, Entzinger (1975), published a paper in which he pled for a minorities policy to 'avoid the formation of minorities groups as described by van Amersfoort'. As of 1976 the public officials of the Ministry of CRM had called on the services of academic researchers, whose reports showed the gravity of the situation. Their activities gained official status in 1978, when the minister set up the Advisory Commission for Research into Minorities (ACOM) with minorities researchers such as van Amersfoort, Bovenkerk, Ellemers, Entzinger, Köbben, Penninx and van Praag among its leading members. The main task of the commission was now to advise the government with regard to its research programme on ethnic minorities. Its very first advise turned out to be particularly influential (ACOM 1979). Herein, ACOM presented its view on the situation, including a definition of ethnic minorities, a description of the social groups that were deemed qualified for this label, and the kind of processes they were supposedly involved in. The theoretical basis for this advise was, again, van Amersfoort's dissertation $(1974,1982)$. This most certainly point to congruity of state and social science research.

Particularly in the late 1970s and 1980s, that was the time when the ethnic minorities policy was still 'under construction', the communis opinio among the leading politicians was that the issue of immigration and the incorporation of immigrants was too sensitive to make to make a hot issue of it. So they reverted to the same old habit of resolving the issue by developing a technocratic compromise, in the process of which social scientific researcher acquired a predominant role. True enough, during this period the political parties were unanimous in their support for the-indeedrather technocratic ethnic minorities policy. For a long time, the majority of sponsored researchers, and remarkably also of independent researchers—all mostly natives—had 
unhesitatingly put their academic work at the service of that policy, thereby taking the advisory reports of the ACOM as the starting point of their research (Rath 1990: 227; 1991; 1993; 1997; see also Penninx 1988b: 34-44). In this process, they were able were able to exert considerable influence on the formation of state policy (Penninx 1988b).

This congruity of state and social science research was enhanced by the continuous exchange of personnel: researchers were appointed as public official, and public officials became researchers. It was, moreover, visible in the researchers' choice of one specific paradigm, the ethnicity paradigm, of which the bases show an interesting parallel with that of the minorities policy. Bovenkerk (1984: 35) rightly says that the development of political economic theory on guest workers in the Netherlands was quite suddenly interrupted, and precisely at the moment that the state incorporated researchers into the bureaucratic apparatus and started to hand out subsidies on a wide scale for politically relevant research. Penninx (1988a: 249n) in his popular review of minorities research cautiously suggests — and remarkably enough buried in a footnote - that the absence of 'the Marxist analytical model' in the Netherlands 'probably' 'in part' is connected with the strong domination of policy-linked research in areas involving minorities.

\section{Conclusions}

What are called ethnic minorities studies are an active sector of social science in the Netherlands. But despite the great production in terms of numbers, the theoretical performance has been rather poor. As the Dutch sociologist Van Doorn (1985: 75) puts it, the problem is 'academic provincialism'. Especially in the 1980s, minorities researchers mainly work within the ethnicity paradigm while ignoring and even rejecting the Marxist class paradigm. Comparing this situation to the one in countries such as France or Britain, this seems rather odd. In this article, it is shown how prominent Dutch researchers disposed of Marxist theory, while showing extremely little knowledge about it. In their view Marxist theory would only offer stereotyped and economistic explanations for social phenomena, is built on a simplistic and pre-eminent division between two sharply distinguished social classes, sees racism as the product of the ruling class who would use it to undermine the position of the working class, ignores ethnic loyalties or at best makes them subordinate to class loyalties, regards the state as the agent of capital, and so on. The adherents of Marxist theory in addition would abjure empiricism and work primarily ideologically. The critics of Marxist theory, however, based their rejection entirely on a limited number of rather out-dated studies, particularly those of Cox (1984) and of Castles and Kosack (1973) which they wrongly 
believed to be representative of the whole of Marxist theory. In this way they showed that they had a rather static and one-dimensional view of a theoretical tendency which has, on the other hand, just displayed a high degree of dynamism and acceptance of new insights-for example, those derived from semiotics - and which currently stands for a multiplicity of different and sometimes mutually competing schools of thought.

The lack of interest among minorities researchers in Marxist theory is not an isolated phenomenon. It is connected to the specific nature of Dutch social science, which is highly politically oriented, and in which the state has a remarkable amount of influence. That minorities research has not looked seriously into what the latest Marxist literature has to offer is hardly scholarly, and throws a doubtful light on the quality of the social sciences in the Netherlands.

This state of affairs is the more to be regretted since neo-Marxist literature offers (nonreductionist) insights into the relation of the subject and its social environment; into the formation of identities and societies; into processes of social division; into the role of the state; into ideologies such as racism; and into the interrelationships between race, ethnicity, gender, class and state. These are in fact precisely those areas which occupy the attention of researchers into postmigration processes. In this connection one might suppose that they draw up an interesting programme based on modern and post-modern variants of Marxist theory, for example, into the way in which in specific historical periods and within specific social contexts certain groups of people — whether migrants or natives — have been ideologically problematized and excluded from certain resources (cf. Bovenkerk, Miles \& Verbunt 1991). In view of the tendency of many Dutch social scientists to form a symbiotic relationship with the state, such a programme should also allow scope for research into the role of the social sciences in these processes

approx. 7100 words 


\section{References}

ACOM (Adviescommissie Onderzoek Minderheden) (1979). Advies Onderzoek Minderheden. The Hague: State Publishing Office.

van Amersfoort, J.M.M. (1974). Immigratie en Minderheidsvorming. Een Analyse van de Nederlandse Situatie 1945-1973. Alphen aan den Rijn: Samsom.

van Amersfoort, J.M.M. (1982a). 'Immigrant en samenleving. Een terreinverkenning', pp. 7-19 in J.M.M. van Amersfoort and H.B. Entzinger (eds), Immigrant en Samenleving. Book issue, Mens en Maatschappij 57. Deventer: Van Loghum Slaterus.

van Amersfoort, H. (1982b). Immigration and the Formation of Minority Groups. The Dutch Experience 1945-1975. Cambridge: Cambridge University Press.

van Amersfoort, H. (1983). 'Migratie-onderzoek, overheidsfinanciering en beleid. Aantekeningen van een participant', Grafiet, 4, pp. 130-154.

van Amersfoort, J.M.M. (1987). Etnische Woonpatronen. Vier Benaderingen van Woonsegregatie Toegepast op Amsterdam. Inaugural lecture. Amsterdamse Sociaal-Geografische Studies 8. Amsterdam: University of Amsterdam, Institute of Social Geography.

van Amersfoort, J.M.M. (1990). 'Leve het positivisme!', pp. 255-266 in F. Bovenkerk, F. Buijs and H. Tromp (eds), Wetenschap en Partijdigheid. Opstellen voor André J.F. Köbben. Assen/Maastricht: Van Gorcum.

van Amersfoort, J.M.M. (1991). 'Van gerepatrieerdenzorg tot allochtonenbeleid. Wetenschap en beleid met betrekking tot immigranten in Nederland', Sociologische Gids, 38 (1), January/February, pp. 24-36.

Bader, V.M. (1985). 'Nieuw racisme of neonationalisme?', Komma, 5 (1), March, pp. 109-143.

Boer, A. de (1982). 'Over de positie van buitenlandse arbeid(st)ers in Nederland', Komma, 3 (2), September, pp. 33-63.

Borghuis, M.G.M. (ed.) (1988). Etnische Minderheden in Nederland. Een Geselecteerde Bibliografie van Sociaal-Wetenschappelijke Publikaties 1945-1986. Muiderberg: Coutinho.

Bovenkerk, F. (1984). 'Rassen of klassen? De politieke economie van de gastarbeid', Intermediair, 20 (47), 23 November, pp. 35-41.

Bovenkerk, F. (1985). 'Over een oud en een nieuw immigranten-proletariaat', De Gids, 148 (3-4), May, pp. 271-278.

Bovenkerk, F. (1989). Er zijn Grenzen. Inaugural lecture. Arnhem: Gouda Quint.

Bovenkerk, F., R. Miles and G. Verbunt (1990). 'Racism, migration and the state in Western Europe. A case for comparative analysis', International Sociology, 5 (4), December, pp. 475-490.

Bovenkerk, F., R. Miles and G. Verbunt (1991). 'Comparative studies of migration and racism in Western Europe. A critical appraisal', International Migration Review, 25 (2), Summer, pp. 375-391.

Brummelhuis, J., P. Cassé, F. Eppings, F. Gimbel, A. Kruyt, E. Kunz-Schmidt, J. de Roos, C. Wallis and G. Zandsteeg. (1975). Gastarbeiders à la Carte. De Gaarkeuken van de Nederlandse Overheid. Maarsen: Ars Aequi Libri.

Carchedi, G. (1979). 'Authority and foreign labour. Some notes on a late capitalist form of capital accumulation and state intervention', Studies in Political Economy, 2, pp. 37-74.

Castles, S., H. Booth and T. Wallace (1984). Here for good. Western Europe's New Ethnic Minorities. London: Pluto Press.

Castles, S. and G. Kosack (1972). 'The function of labour immigration in Western European capitalism', New Left Review, 73, May-June, pp. 3-21.

Castles, S. and G. Kosack (1973). Immigrant Workers and Class Structure in Western Europe. London: Oxford University Press.

Choenni, A. (1997). Veelsoortig Assortiment. Allochtoon Ondernemerschap in Amsterdam als Incorporatietraject 1965-1995. PhD dissertation University of Amsterdam.

Cohen, R. (1987). The New Helots. Migrants in the International Division of Labour. Aldershot: Gower.

Cox, O.C. (1959). Caste, Class, and Race. A Study in Social Dynamics. New York: Monthly Review Press, (1948).

van Doorn, J.A.A. (1985). 'Het miskende pluralisme. Een herformulering van het minderhedenvraagstuk', pp. 67-96 in G.G. Cain et al., Etnische Minderheden. Wetenschap en Beleid. Meppel: Boom. 
Ellemers, J.E. (1978). 'Minderheden en beleid in Nederland. De opkomst van een "nieuw proletariaat"', Intermediair, 14 (13), 31 March, pp. 1-7, 55, 59.

Ellemers, J.E. and M.G.B. Borghuis (1988). 'Inleiding bij de bibliografie', pp. 7-12 in M.G.M. Borghuis (ed.), Etnische Minderheden in Nederland. Een Geselecteerde Bibliografie van SociaalWetenschappelijke Publikaties 1945-1986. Muiderberg: Coutinho.

Entzinger, H.B. (1975). 'Nederland immigratieland? Enkele overwegingen bij het overheidsbeleid inzake allochtone minderheden', Beleid en Maatschappij, 2 (12), pp. 326-336.

Entzinger, H.B. (1984). Het Minderhedenbeleid. Dilemma's voor de Overheid in Nederland en Zes Andere Immigratielanden in Europa. Meppel: Boom.

Entzinger, H.B. (1987a). 'Een kleine wereld', Migrantenstudies, 3 (4), p. 2-20.

Entzinger, H.B. (1987b). 'Race, class and the shaping of a policy for immigrants. The case of the Netherlands', International Migration, 25 (1), March, pp. 5-20.

Esser, H. (1980). Aspekte der Wanderungssoziologie. Assimilation und Integration von Wanderern, Ethnische Gruppen und Minderheiten. Eine Handlungstheoretische Analyse. Darmstadt/Neuwied: Luchterhand.

Feddema, R. (1979). 'De organisatie van de ontwikkeling in de thuisregio', pp. 31-40 in M. van Nieuwstadt et al., Gastarbeid. Eindhoven: Technische Hogeschool Eindhoven, Studium Generale.

Feddema, R. (1984). 'De buitenlandse arbeider en de vakbond in de tang', Dunk, 2, summer, pp. 17-26.

Fijnaut, C. (1990). 'Ideologie en misdaad in de justitiële beleidsplannen', Tijdschrift voor Criminologie, Special issue 'Justitieel beleid in beweging' (ed. by B. Berghuis and H. Franke), 32 (4), pp. 268277.

Gabriel, J. and G. Ben-Tovim (1978). 'Marxism and the concept of racism', Economy and Society, 7 (2), May, pp. 118-154.

Gastelaars, M. (1985). Een Geregeld Leven. Sociologie en Sociale Politiek in Nederland 1925-1968. Amsterdam: Sua.

Gelling, M., G. de Jong and E. Schoemaker (1990). 'Minderhedenbeleid, wetenschap en politiek. Over de verhouding van wetenschap en politiek bij de totstandkoming van het minderhedenbeleid in Nederland', WO Nieuwsnet, Special issue 'Sociaal-culturele wetenschappen. Wetenschappelijke essays' (ed. by R. Hagendijk, H. Harbers and E. Hicks), pp. 5-26.

George, H. Jr. (1984). American Race Relations Theory. A Review of Four Models. Lanham: University Press of America.

Goudsblom, J. (1967). Dutch Society. New York: Random House.

Goudsblom, J. (1974). Balans van de Sociologie. Utrecht/Antwerp: Het Spectrum.

Gowricharn, R. (1987). Migranten en het Arbeidsvraagstuk in Rotterdam. Stafrapport no. 3. Rotterdam: Stichting KROSBE.

Heemskerk, C. (1971). 'De (gast)arbeid', NESBIC Bulletin, 6 (10-11), October/November, pp. 1-144.

Hira, S. (1985). Racisme en Fascisme. Ontstaan en Bestrijding. Weesp: Wereldvenster.

Hisschemöller, M. (1985). 'Oude tradities en nieuwe obstakels. Over nationaal antifascisme en nieuw antiracisme', Komma, 5 (1), March, pp. 85-108.

Hisschemöller, M. (1988). 'Ras, klasse en natie', p. 27-42 in M. Hisschemöller (ed.), Een Bleek Bolwerk. Racisme en Politieke Strategie. Amsterdam: Pegasus.

Hoppe, R. (ed.) (1987). Etniciteit, Politiek en Beleid in Nederland. Politikologische Studies VU 5. Amsterdam: Free University Press.

de Jong, W. (1986). Inter-Etnische Verhoudingen in een Oude Stadswijk. Delft: Eburon.

de Jongh, R., M. van der Laan and J. Rath (1984). FNV'ers aan het Woord over Buitenlandse Werknemers. Issue no. 16. Leiden: University of Leiden, Centre for the Study of Social Conflicts (COMT).

Jongkind, F. (1992). 'Ethnic identity, societal integration and migrants' alienation in state-policy and academic research in the Netherlands', Ethnic and Racial Studies, 15 (3), July, pp. 365-380.

Junger, M. (1992). Review of Jan Rath, Minorisering: de sociale constructie van 'etnische minderheden', Mens en Maatschappij, 67 (3), August, pp. 334-335.

Kalpaka, A. and N. Räthzel (eds.) (1992). Rassismus und Migration in Europa. Beitrage des Kongresses 'Migration und Rassismus in Europa', Hamburg, 26. bis 30. September 1990. ArgumentSonderband AS 201. Hamburg/Berlin: Argument Verlag.

Köbben, A.J.F. (1980). 'Het heilig vuur. Moeilijkheden en mogelijkheden bij onderzoek inzake minderheden', Intermediair, 16 (49), 5 December, pp. 1-7. 
Köbben, A.J.F. and J.J. Godschalk (1985). Een Tweedeling van de Samenleving? OSA-Voorstudie no. 10. Leiden: University of Leiden, Centre for the Study of Social Conflicts (COMT).

Lijphart, A. (1975). The Politics of Accommodation. Pluralism and Democracy in the Netherlands. Second print (1968). Berkeley, California: University of California Press.

Lucassen, J., R. Penninx and A. Zwinkels (1973a). 'Trekarbeid van Middellandse Zeegebieden naar WestEuropa. Een bibliografisch overzicht I', Kroniek van Afrika, 13 (1), pp. 12-38.

Lucassen, J., R. Penninx and A. Zwinkels (1973b). 'Trekarbeid van Middellandse Zeegebieden naar West-Europa. Een bibliografisch overzicht II', Kroniek van Afrika, 13 (2), pp. 85-118.

Lucassen, J., R. Penninx and A. Zwinkels (1973c). 'Trekarbeid van Middellandse Zeegebieden naar West-Europa. Een bibliografisch overzicht III', Kroniek van Afrika, 13 (3), pp. 190-235.

Lucassen, J., R. Penninx, L. van Velzen and A. Zwinkels (1974). Trekarbeid. Van de Middellandse Zeegebieden naar West-Europa. Een Bibliografisch Overzicht. Sunschrift 84. Nijmegen: Socialistische Uitgeverij Nijmegen (SUN).

Marshall-Goldschvartz, A.J. (1973). The Import of Labour. The Case of the Netherlands. Rotterdam: University Press Rotterdam.

Miles, R. (1980). 'Class, race and ethnicity. A critique of Cox's theory', Ethnic and Racial Studies, 3 (2), April, pp. 169-187.

Miles, R. (1982). Racism and Migrant Labour. London: Routledge \& Kegan Paul.

Miles, R. (1984). 'Marxism versus the sociology of "race relations"', Ethnic and Racial Studies, 7 (2), April, pp. 217-237.

Miles, R. (1989). Racism. London: Routledge.

Miles, R. and A. Phizacklea (1984). White Man's Country. Racism in British Politics. London and Sydney: Pluto Press.

Miles, R. and V. Satzewich (1990). 'Migration, racism and “postmodern” capitalism', Economy and Society, 19 (3), August, pp. 334-358.

Monsma, G. (1987). Programmering in de Praktijk. Een Reconstructie-Onderzoek naar

Researchprogramma's in het Minderhedenonderzoek in Nederland. SCO-Rapport no. 97.

Amsterdam: University of Amsterdam, Centre for Educational Research (SCO).

Ng, R. (1989). 'Sexism, racism and Canadian nationalism', Socialist Studies/ Etudes Socialistes. A Canadian annual, 'Race, class, gender. Bonds and barriers', 5, pp. 10-25.

van Nieuwstadt, M. (1979). 'Achtergronden en oorzaken van de gastarbeid', pp. 3-10 in M. van Nieuwstadt et al., Gastarbeid. Eindhoven: Technische Hogeschool Eindhoven, Studium Generale.

Omi, M. and H. Winant (1986). Racial Formation in the United States. From the 1960s to the 1980s. New York: Routledge \& Kegan Paul.

Pahl, R. (1970). Whose City? London: Longman.

Penninx, R. (1988a). Minderheidsvorming en Emancipatie. Balans van Kennisverwerving ten aanzien van Immigranten en Woonwagenbewoners. Alphen aan den Rijn: Samsom.

Penninx, R. (1988b). Wie Betaalt, Bepaalt? De Ontwikkeling en Programmering van Onderzoek naar Migranten, Etnische Minderheden en Woonwagenbewoners, 1955-1985, met Speciale Aandacht voor de Rol van de Overheid. Amsterdamse Sociaal-Geografische Studies 13. Amsterdam: University of Amsterdam, Institute of Social Geography.

Penninx, R. (1989). 'Ethnic groups in the Netherlands. Emancipation or minority group-formation?', Ethnic and Racial Studies, 12 (1), January, pp. 84-99.

Penninx, R. and L. van Velzen (1977). Internationale Arbeidsmigratie. Uitstoting uit 'Thuislanden' en Maatschappelijke Integratie in 'Gastlanden' van Buitenlandse Arbeiders. Sunschrift 124. Nijmegen: Socialistische Uitgeverij Nijmegen (SUN).

Praag, C.S. van (1987). 'Onderzoek naar etnische minderheden in Nederland', Sociologische Gids, 34 (3), May/June, pp. 159-175.

Przeworski, A. (1977). 'Proletariat into class. The process of class formation from Karl Kautsky's The class struggle to recent controversies', Politics and Society, 7 (4), pp. 343-401.

Rath, J. (1990). 'De overheid en het "minderhedenonderzoek"“, pp. 225-240 in F. Bovenkerk, F. Buijs and H. Tromp (eds), Wetenschap en Partijdigheid. Opstellen voor André J.F. Köbben. Assen/Maastricht: Van Gorcum.

Rath, J. (1991). Minorisering: de Sociale Constructie van 'Etnische Minderheden'. Amsterdam: Sua.

Rath, J. (1993). 'La construction sociale des minorités ethniques aux Pays-Bas et ses effets pervers', pp. 17-41 in M. Martiniello and M. Poncelet (eds.), Migrations et Minorités Ethniques dans l'Espace Européen. Bruxelles: De Boeck. 
Rath, J. (1997). 'Das strenge Gesicht von Frau Antje. Die andere Seite des niederländischen Modells für die Integration ethnischer Minderheiten', Neue Praxis, 26 (6), December, pp. 479-494.

Rath, J. and R. Kloosterman (1999). 'Outsiders' business. A Critical Review of Research on Immigrant Entrepreneurship in The Netherlands', International Migration Review. (forthcoming).

van Schendelen, M.P.C.M. (ed.) (1984). Consociationalism, Pillarization and Conflict-Management in the Low Countries. Acta Politica (Special issue) XIX January, pp. 1-178.

Schuster, J. (1992). 'The state and post-war immigration into the Netherlands. The racialisation and assimilation of Indonesian Dutch', European Journal of Intercultural Studies, 3 (1), pp. 47-58.

Shadid, W.A.R. and P.S. van Koningsveld (1986). 'Minderheden in de gezondheidszorg. Evaluatie van recent onderzoek', Migrantenstudies, 2 (4), pp. 54-63.

Solomos, J. (1986). 'Varieties of Marxist conceptions of "race", class and the state. A critical analysis', pp. 84-109 in J. Rex and D. Mason (eds), Theories of Race and Ethnic Relations. Cambridge: Cambridge University Press.

Strijbosch, F. (1992). 'Hoe heilloos is nu eigenlijk minorisering', Migrantenstudies, 8 (3), pp. 34-43.

Theunis, S. (1979). Ze Zien Liever Mijn Handen Dan Mijn Gezicht. Buitenlandse Arbeiders in Ons Land. Baarn: Wereldvenster.

Tinnemans, W. (1991). 'Minderhedenonderzoek. Meer politiek dan wetenschap', Intermediair, 27 (13), 29 March, pp. 45-53.

van Twist, K. (1977). Gastarbeid Ongewenst. De Gevestigde Organisaties en Buitenlandse Arbeiders in Nederland. Baarn: In den Toren.

van de Velde, B., and J. van Velzen (1978). 'De Nederlandse vakbonden, internationale solidariteit en buitenlandse werknemers. Ideologie en werkelijkheid', pp. 166-188 in F. Bovenkerk (ed.), Omdat Zij Anders Zijn. Patronen van Rasdiscriminatie in Nederland. Meppel/Amsterdam: Boom.

Waardenburg, J.D.J. (1986). 'Iets over onderzoek betreffende de islam bij etnische minderheden', Migrantenstudies, 2 (1), pp. 39-48.

Wright, E.O. (1980). 'Varieties of Marxist conceptions of class structure', Politics and Society, 9 (3), pp. 323-370. 


\section{Abstract}

What are called 'ethnic minorities studies' are an active sector of social science in the Netherlands. But despite the great production in terms of numbers, the theoretical performance is rather poor. Minorities researchers only work within the ethnicity paradigm while ignoring and even rejecting the Marxist class paradigm. In this article, it is shown how prominent Dutch researchers dispose of Marxist theory, while showing extremely little knowledge about it. It is further shown that the lack of interest among minorities researchers in Marxist theory is connected to the specific nature of Dutch social science, which is highly politically oriented, and in which the state has a remarkable amount of influence. 


\section{Author}

Dr Jan Rath received his MA degree in cultural anthropology and urban studies and a $\mathrm{PhD}$ from Utrecht University, and has also been active in political science, sociology of law, economics and economic sociology. He previously held academic posts in the University of Leiden, Utrecht University, the Catholic University of Nijmegen, and the University of California at Los Angeles, and is now Senior Researcher and Project Manager in the interfaculty Institute for Migration and Ethnic Studies (IMES) at the University of Amsterdam. $\mathrm{He}$ is interested in the economic incorporation of immigrants in advanced urban economies, in particular their self-employment and its relationship with the wider economy, the institutional framework and the embeddedness of entrepreneurs in social networks. He is the founding and managing editor of the Dutch quarterly journal Migrantenstudies and editor of the Netherlands' Journal of Sociology. He is author of numerous articles, book chapters and reports on the sociology, politics and economics of post-migratory processes amongst others Minorisation: The Social Construction of 'Ethnic Minorities' (Sua, 1991), co-author of Western Europe and its Islam: The Netherlands, Belgium and the United Kingdom React to an Emerging Religious Community (forthcoming, 1999), editor of Immigrant Businesses in the Urban Economic Fringe (Macmillan 1998), and co-editor of a book on Immigrant Self-Employment in the Netherlands (Het Spinhuis, 1998). The author wish to thank the Institute for Sociology of Law at the Catholic University of Nijmegen for their support in writing this article. 
1 This includes books as well as articles in journals and edited volumes. In fact, the library of the Leiden Institute for Social Research (LISWO), that since 1992 has absorbed the library of the former Advisory Commission for Research into Minorities (ACOM), at this moment possesses no less than 11,000 titles, including a number of policy documents and MA dissertations.

For an elaboration of this view see also Penninx (1989).

This is for example the case in the work of Choenni (1997) who-instead of affiliating with theoretical insights from economics or economic sociology—sought refuge in culturalist notions and in van Amersfoort's thesis (1982) on the formation of ethnic minority groups. In 1971 Heemskerk explained in the Nesbic Bulletin how far guest workers were a consequence of inequalities in economic development. In the centres of capitalism they made up a reserve army of labour, completely at the service of the bourgeoisie which only used their productive power. The bourgeoisie paved the way for racism and other 'false doctrines' by exaggerating the differences between groups of workers. All in all guest workers led to a considerable weakening of the working class. These kinds of argument are also found in the Sunschrift by Lucassen et al. (1974; see also Lucassen, Penninx and Zwinkels 1973a, 1973b and 1973c), and by Penninx and Van Velzen (1977), in a thesis by Marshall-Goldschvartz (1974), the Ars Aequi special issue on 'Gastarbeiders à la Carte' by Brummelhuis et al. (1975), the Studium Generale articles by Feddema (1979) and Nieuwstadt (1979), in Carchedi (1979) and to some degree in Theunis (1979) and Van Twist (1977). The position of the classical interest group of the working class, the trades union, is the subject of studies by Van de Velde and Van Velzen (1978), Feddema (1984) and De Jong, Van der Laan and Rath (1984), though these last also incline in this study towards the ethnicity paradigm. Other researchers describe the proletarian status of 'foreign workers' (Bovenkerk 1985) or 'minorities' (Ellemers 1978) using it to underline the historical similarities between these categories and native-born workers. Köbben and Godschalk (1985) emphasize the ethnic differentiation of this working class, while Gowricharn (1987) particularly refers to class differences within the immigrant population. Bader (1985) and Hira (1985) discuss the 
connection between racism and capitalism. Hisschemöller (1985 and 1988b) sets out the relationships between internationalism, nationalism, the antiracist struggle and class solidarity, and criticizes the inadequate way in which 'classical' Marxist theorists approach the phenomenon of racism. De Boer (1982) describes and analyses state intervention and the role of immigrant interest groups. Among more recent work are Bovenkerk (1984; 1989; see also Bovenkerk, Miles and Verbunt 1990 and 1991), Rath (1990, 1991a, 1991b and 1993) and Schuster (1992) who concentrate on the role of the state and on its share in the construction of problem groups. They condemn the orthodox economic analyses in which the state is exclusively portrayed as buttressing capital. There were other criticisms. Strijbosch (1992: 37) stated that 'many Marxists and neoMarxists have a sense of superiority', while Junger (1992: 335) qualified the expansion of neo-Marxist opinions as a 'danger'. Both, however, made these suggestions without further explanation.

6 Whether this is really so, is in any case a moot point in British social sciences. Marxistoriented researchers such as Anthias, Gilroy and Solomos do indeed hold that race is a social construct, but believe that this concept-because of the significance that people give to it in daily life-does have a certain value for analysis.

7 The conceptual problem is by no means unique. What should one think of such concepts as 'ethnic groups (or groupings)', 'ethnic minorities' or 'integration'? Van Amersfoort (1990: 263) comments on this in another article, but did not in this case go so far as to reject completely his theoretical approach.

$8 \quad$ The distinguished Dutch sociologist Goudsblom (1967: 63) wrote something of this kind twenty-five years ago. In a later article he accuses Marxist sociologists of scholasticism, and suggests that they have a strong tendency towards preaching and denunciation (1974: 83-84). 